\title{
EPR and DRIFT spectroscopic characterization of humic fractions during composting of sawdust and paper mill sludge
}

\author{
Claudia Maria Branco de Freitas Maia ${ }^{1}$, Cristiane Regina Budziak Fukamachi², Alessandro Piccolo ${ }^{3}$, Antonio Sálvio Mangrich ${ }^{4}$ \\ ${ }^{1}$ Embrapa Florestas, C.P. 319, CEP 83411-000, Colombo, PR, Brasil \\ ${ }^{2}$ Universidade Tecnologica Federal do Parana, Coordenação de Química, Via do Conhecimento, Km 1, CEP 85503-390, Pato Branco, PR, Brasil \\ ${ }^{3}$ Università di Napoli Federico II, Dipartimento di Scienze del Suolo, della Pianta, dell'Ambiente, e delle Produzioni Animali, Portici, Itália \\ ${ }^{4}$ Universidade Federal do Paraná, Departamento de Química, P.O. Box. 19081, CEP 81531-970, Curitiba, PR, Brasil
}

*Autor correspondente:

claudia.maia@cnpf.embrapa.br

Termos para indexação:

Substâncias húmicas

UV-vis

Index terms:

Humic substances

UV-Vis

Humification
Humificação

\begin{abstract}
The spectroscopic characteristics (DRIFT, UV-visible and EPR) of humic fractions were studied during composting of sawdust and paper mill sludge. Infrared spectroscopy reveals a compost rich in hydroxyl and alkyl groups and carboxylates and carbohydrates. The alkyl fraction is abundant in the humic acids and humin. The decreasing of the E4/E6 ratio during composting indicates an enhancement of the organic chains number, with conjugated double bonds. This decreasing would correspond to a reduction of the lignin content and/or formation of porphyrins. The EPR shows that humin presents the highest concentration of free radical and the lowest intensities of the $\mathrm{Fe}^{3+}$.
\end{abstract}

\section{Caracterização espectroscópica (RPE e DRIFT) das frações húmicas durante a compostagem de lodo de fábrica de papel e serragem}

Publicado em 29/06/2012

\section{Introdution}

Composting is an environmentally clean and economic way to recycle industrial wastes. This can be defined as a bio-oxidative and exothermic controlled process for treatment and stabilization of organic materials. During composting, mineralization leads to production of water, $\mathrm{CO}_{2}, \mathrm{CH}_{4}$ and $\mathrm{NH}_{3}$, and the humification process produces stabilized organic matter, which can be used as soil fertilizer. Two terms are used to define the degree of decomposition of organic matter during composting: stability and maturity (Veeken et al., 2000).
Stability is related to microbial activity and depends directly on content of easily degradable components as carbohydrates and amino acids. The use of unstable compost in soils can lead to losses of soil organic matter (SOM) and nitrogen and nutrients deficiency, affecting not only the soil fertility but also the structure stability. The humification process is one of the parameters used to indicate the compost maturity (Goyal et al., 2005). Humic substances (HS) are the major components of composts and have relevant roles in the physical, chemical and fertility properties of SOM (Stevenson,1994) as cation exchange and water 
retention capacities, aggregation and porosity. Humic substances (HS) are naturally occurring supramolecular structures, ubiquitous in water, soil, and sediments, of paramount importance in controlling both the fate of environmental pollutants and the biogeochemistry of organic carbon in the global ecosystem (Piccolo et al, 2005). Despite their role in the sustainability of life, the basic chemical nature is still matter of investigation (Piccolo, 2001; Nebbioso \& Piccolo, 2012).

This paper aims to study the process of HS formation during the composting of Pinus taeda sawdust and paper mill sludge. Chemical (elemental analysis) and spectroscopic (Diffuse Reflectance Infrared Fouriertransform - DRIFT; UV-visible and Electronic Paramagnetic Resonance - EPR) characteristics of humic fractions (humic acid, fulvic acid and humin) were studied during different composting times.

\section{Materials and methods}

\section{Composting}

Sawdust of Pinus taeda wood and paper mill sludge were used as parental material to compost. Both materials were mixed in equals volumes (fresh material) and composted in a 13-ton commercial Kneer ${ }^{\circledR}$ reactor (Tibagi Sistemas Ambientais Ltda., Paraná, Brazil), under temperature and aeration control. Samples were taken from the medium depth of the reactor at 0,2 , 8 and 15 days of composting. After two weeks, the compost was dropped to a maturation yard and samples were taken at 22 and 29 days of composting.

\section{Humic fractions extraction}

Humic fractions were extracted from compost samples by using standard methods (Piccolo et al., 2000). The compost samples were shaken overnight in the mixture of $0.5 \mathrm{~mol} \mathrm{~L}^{-1} \mathrm{NaOH}$ and $0.1 \mathrm{~mol} \mathrm{~L}^{-1} \mathrm{Na}_{2} \mathrm{P}_{2} \mathrm{O}_{7}$ solution under atmosphere enriched with $\mathrm{N}_{2}$. The humic acid (HA) fraction were precipitated from alkaline extracts by lowering the $\mathrm{pH}$ to 1 with $\mathrm{HCl}$ and purified by three cycles of dissolution (using sodium hydroxide beads) followed by reprecipitation in $\mathrm{HCl}$. The HAs were treated with a $0.5 \%(\mathrm{v} / \mathrm{v}) \mathrm{HCl}-\mathrm{HF}$ solution for $48 \mathrm{~h}$, dialyzed against distilled water until $\mathrm{Cl}$ free. The fulvic acid (FA) fraction, the humic material left in solution after the first precipitation of $\mathrm{HAs}$ at $\mathrm{pH} 1$, were purified using an Amberlite XAD-8 resin, eluting with a $1 \mathrm{~mol} \mathrm{~L}^{-1} \mathrm{NaOH}$ solution, and, after adjusting the $\mathrm{pH}$ to 5 , dialyzed and freeze-dried. The humin fraction (HU), the solid fraction that remains after the HA extraction, was treated twice with a $10 \%$ HF solution for $24 \mathrm{~h}$, and extracted as the humic fraction, dialyzed and freeze-dried. All HA samples were measured for their ash content (w/w).

\section{Elemental analysis}

The $\mathrm{C}, \mathrm{H}$ and $\mathrm{N}$ contents of humic fractions were measured by a Fisons EA1108 analyzer. The O+S contents were obtained by difference.

\section{DRIFT, DRUV-Vis and EPR}

The freeze-dried fractions of FA, HA and HU were mixed and grounded with $\mathrm{KBr}(2 \%)$. The spectra were acquired by using a Perkin Elmer FTIR Spectrometer (Spectrum One) with an accessory for diffuse reflectance sampling (DRIFT). The operating range was from 400 to $4,000 \mathrm{~cm}^{-1}$, with a $0.2 \mathrm{~cm}^{-1}$ resolution and 16 scans were recorded for each sample.

The electronic spectra in the UV-Vis region of HA, FA and HU fractions were recorded in the solid state. Diffuse reflectance ultraviolet-visible spectroscopy (DRUV-Vis) was performed by using a Shimadzu UV2401 PC spectrophotometer with integrating sphere accessory. The solid material was ground in a pan grinder to 200 mesh size, and then analyzed after being compressed carefully in the spectrometer cell. The $\mathrm{E}_{2} /$ $\mathrm{E}_{4}$ ' and the $\mathrm{E}_{4} / \mathrm{E}_{6}$ ratios correspond to the absorbance ratio at $270 \mathrm{~nm}$ over $407 \mathrm{~nm}$ ratio and at $465 \mathrm{~nm}$ over $665 \mathrm{~nm}$, respectively (Jerzykiewicz et al.,1999; Chen et al.,1977).

Electronic paramagnetic resonance experiments were carried out by using a Bruker ESP 300E spectrometer, according to conditions mentioned elsewhere (Maia et al., 2001). The HA, FA and HU fractions were analyzed at solid state, at room temperature and at $77 \mathrm{~K}$ (liquid $\mathrm{N}_{2}$ ).

\section{Results and discussion}

The compost obtained from sawdust and paper mill sludge showed a high content in humic acids $7 \%$ in average) and very low content in humin and fulvic acids, even in the very beginning of composting process ( Maia, 2003). These results reflected the high content of paper mill sludge in humic acids (Maia e at al., 2001). 


\section{Elemental analysis}

The elemental analyses showed an average content of C, $\mathrm{H}, \mathrm{N}$ of $58 \%, 7 \%$ and $3 \%$ for HA samples, $30 \%, 4 \%$ and $3 \%$ for $\mathrm{FA}$, and $43 \%, 5 \%$ and $2 \%$ for HU samples, respectively (Table1). Only for humic acids, the ash content was measured just for humic acids by the weight loss after

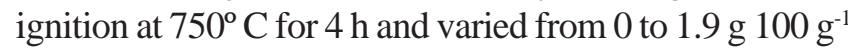
and therefore, except for this fraction, the $\mathrm{C}, \mathrm{H}, \mathrm{N}$ values were not calculated on ash-free basis.

High sulfur content is expected because the sludge comes from a Kraft paper industry. Although a previous analysis

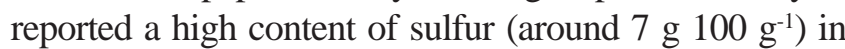
the $\mathrm{NaOH}$-extracted HA fraction (Budziak et al., 2004), only the atomic mass of oxygen was considered for the $\mathrm{O} / \mathrm{C}$ ratios calculations. The FA fractions are the richest in oxygen+sulfur and showed the lowest $\mathrm{C} / \mathrm{N}$ ratio and the highest $\mathrm{O} / \mathrm{C}$ ratio (Table 2), indicating structures with more oxygenated functional groups for this fraction, as expected.

\section{Diffuse reflectance ultraviolet-visible spectroscopy (DRUV-VIS)}

The solid state UV-Vis spectra of HA, FA and HU region, showed a constant intensity variation that is typical of HS (Figure 1). The $\mathrm{E}_{4} / \mathrm{E}_{6}$ ratio is used as a humification index and, for samples in solution, humic acids is usually smaller than 5.0 and that for fulvic acids ranges from 6.0 to 8.5 (Stevenson, 1994). The low $\mathrm{E}_{4} / \mathrm{E}_{6}$ ratios are directly related to the increasing conjugation of simple and double bonds of humic structures. These results are usually interpreted as condensed aromatic carbon in humic fractions extracted from soils, although in fresh humus it could also be due to conjugated double bonds in unsaturated aliphatic carbon chains. This chemical characteristic is not dependent on the concentration of the humic material but varies according to its parental material (Santos et al., 1999).

Table 1. Elemental analysis of humic fractions (\%) from compost at different composting times.

\begin{tabular}{|c|c|c|c|c|c|c|c|c|c|c|c|c|}
\hline \multirow{2}{*}{$\begin{array}{l}\text { Time } \\
\text { (days) }\end{array}$} & \multicolumn{4}{|c|}{ Humic acid (ash free) } & \multicolumn{4}{|c|}{ Fulvic acid } & \multicolumn{4}{|c|}{ Humin } \\
\hline & C & $\mathbf{H}$ & $\mathbf{N}$ & $\mathbf{O}+\mathbf{S}$ & C & $\mathbf{H}$ & $\mathbf{N}$ & $\mathbf{O}+\mathbf{S}$ & C & $\mathbf{H}$ & $\mathbf{N}$ & $\mathrm{O}+\mathrm{S}$ \\
\hline 0 & 58.2 & 7.0 & 3.4 & 31.4 & 27.3 & 2.7 & 4.0 & 65.9 & 50.6 & 6.3 & 2.7 & 40.4 \\
\hline 2 & 58.6 & 6.8 & 3.4 & 31.2 & 31.0 & 4.0 & 3.1 & 61.9 & 44.7 & 5.7 & 2.4 & 47.2 \\
\hline 8 & 58.1 & 6.7 & 3.4 & 31.8 & 31.1 & 4.6 & 3.7 & 60.6 & 43.1 & 5.4 & 2.6 & 48.9 \\
\hline 15 & 58.2 & 7.5 & 3.3 & 31.1 & 32.6 & 4.3 & 3.7 & 59.3 & 35.9 & 3.7 & 1.8 & 58.5 \\
\hline 22 & 57.3 & 6.5 & 3.5 & 32.7 & 29.5 & 3.2 & 3.4 & 63.8 & 51.7 & 6.4 & 2.4 & 39.4 \\
\hline 29 & 58.2 & 7.1 & 3.7 & 31.0 & 28.3 & 4.4 & 2.9 & 64.3 & 32.1 & 3.5 & 1.7 & 62.6 \\
\hline
\end{tabular}

Table 2. Atomic ratios (H/C, $\mathrm{C} / \mathrm{N}$ and $\mathrm{O} / \mathrm{C}$ ) of humic fractions extracted from compost, during composting process (\%).

\begin{tabular}{ccccccccccc}
\hline \multirow{2}{*}{$\begin{array}{c}\text { Time } \\
\text { (days) }\end{array}$} & \multicolumn{3}{c}{ Humic acid } & \multicolumn{3}{c}{ Fulvic acid } & \multicolumn{3}{c}{ Humin } \\
\cline { 2 - 11 } & H/C & C/N & O/C & H/C & C/N & O/C & H/C & C/N & O/C \\
\hline 0 & 1.4 & 19.7 & 0.4 & 1.2 & 7.9 & 1.8 & 1.5 & 21.9 & 0.6 \\
2 & 1.4 & 20.0 & 0.4 & 1.5 & 11.7 & 1.5 & 1.5 & 21.6 & 0.8 \\
8 & 1.4 & 19.8 & 0.4 & 1.8 & 9.9 & 1.5 & 1.5 & 19.3 & 0.8 \\
15 & 1.5 & 20.7 & 0.4 & 1.6 & 10.2 & 1.4 & 1.2 & 23.0 & 1.2 \\
22 & 1.4 & 19.0 & 0.4 & 1.3 & 10.1 & 1.6 & 1.5 & 24.5 & 0.6 \\
29 & 1.5 & 18.4 & 0.4 & 1.9 & 11.2 & 1.7 & 1.3 & 21.8 & 1.5 \\
\hline
\end{tabular}



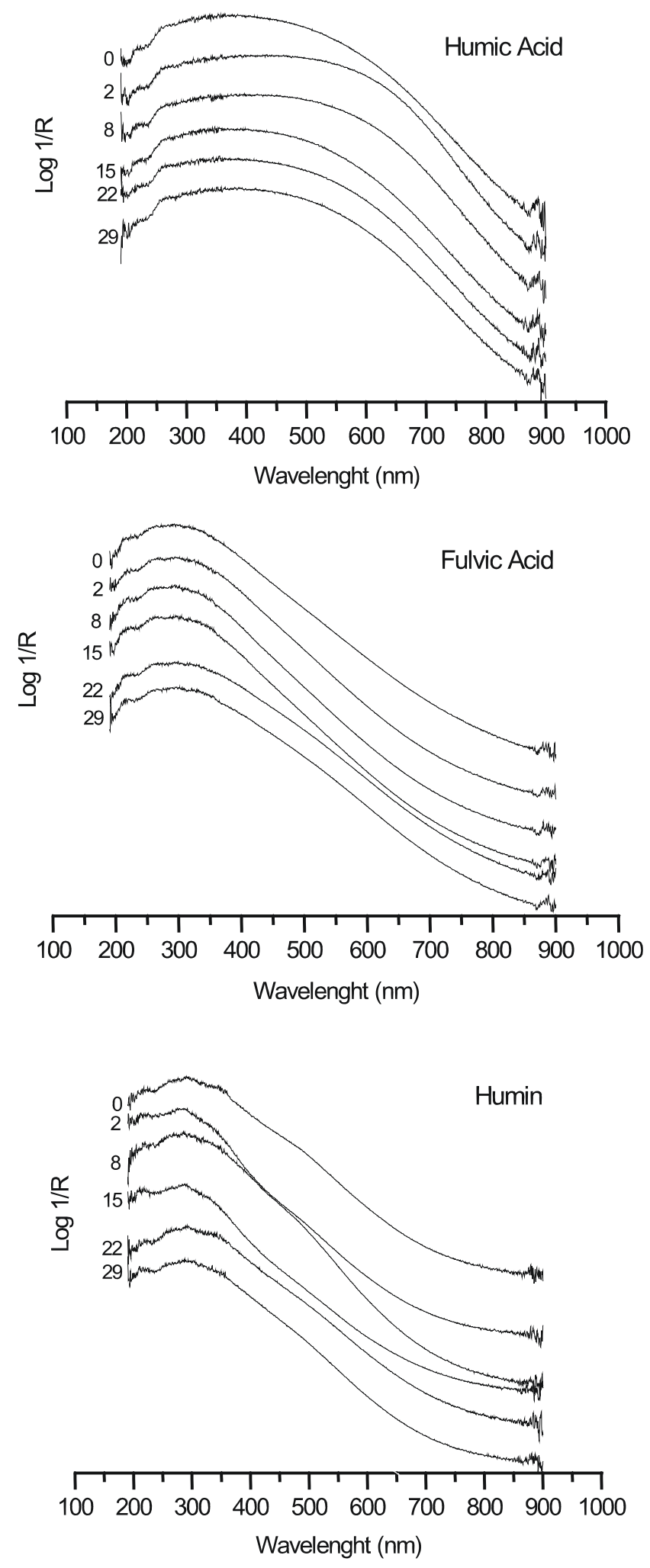

Figure 1. Reflectance Spectra of UV-Vis of Humic acid and Fulvic acid and Humin at different composting time.
The low $\mathrm{E}_{4} / \mathrm{E}_{6}$ ratios (Table 3) also suggests there may be interactions of smaller molecular units, via chelation of metal ions as hard $\mathrm{Fe}^{3+}$ by cathecol-like groups arising from demethylation of methoxyls from structures such as syringil and/or guaiacyl (Jerzykiewicz et al., 1999). At solid state, the $\mathrm{E}_{4} / \mathrm{E}_{6}$ ratio is even smaller due to the intermolecular interaction inherent to the solid state, besides an increasing of conjugated bounds (Budziak et al., 2004).

Table 3. $\mathrm{E}_{2} / \mathrm{E}_{4}$ ' ratio (absorbances at $270 \mathrm{~nm}$ and $407 \mathrm{~nm}$ ) and $\mathrm{E}_{4} / \mathrm{E}_{6}$ ratio (absorbances at $465 \mathrm{~nm}$ and $665 \mathrm{~nm}$ ) of humic acid, fulvic acid and humin at different composting time.

\begin{tabular}{ccccccc}
\hline \multirow{2}{*}{ Time } & \multicolumn{2}{c}{ Humic acid } & \multicolumn{2}{c}{ Fulvic acid } & \multicolumn{2}{c}{ Humin } \\
\cline { 2 - 7 } (Days) & $\mathbf{E}_{\mathbf{2}} / \mathbf{E}_{\mathbf{4}}$, & $\mathbf{E}_{\mathbf{4}} / \mathbf{E}_{\mathbf{6}}$ & $\mathbf{E}_{\mathbf{2}} / \mathbf{E}_{\mathbf{4}} \boldsymbol{\mathbf { E }}_{\mathbf{4}} / \mathbf{E}_{\mathbf{6}}$ & $\mathbf{E}_{\mathbf{2}} / \mathbf{E}_{\mathbf{4}}{ }^{\prime}$ & $\mathbf{E}_{\mathbf{4}} / \mathbf{E}_{\mathbf{6}}$ \\
\hline 0 & 0.96 & 1.50 & 1.18 & 2.51 & 1.23 & 3.30 \\
2 & 0.94 & 1.31 & 1.20 & 2.98 & 1.43 & 3.81 \\
8 & 0.96 & 1.55 & 1.22 & 2.91 & 1.23 & 3.57 \\
15 & 0.96 & 1.36 & 1.20 & 2.85 & 1.41 & 4.23 \\
22 & 0.97 & 1.48 & 1.14 & 2.46 & 1.22 & 3.05 \\
29 & 0.96 & 1.54 & 1.14 & 2.43 & 1.23 & 3.68 \\
\hline
\end{tabular}

A lower $E_{2} / E_{4}^{\prime}$ ratio is related to an enhancement in porphyrins structures (absorption at $407 \mathrm{~nm}$ attributed to the Soret band) with respect to lignin structures. Metal porphyrins in compost may come from paper mill sludge or even from biological syntheses (e.g. by actinomycetes) during the composting process (Guimarães, 2001). A higher E2/E4' ratio suggests a larger participation of terrestrial plants with high content of lignin (absorption at $270 \mathrm{~nm}$ ) (Foken \& Liebezeit, 2000).

\section{DRIFT Spectroscopy}

The infrared spectra of HA, FA and HU samples showed typical bands of humic substances (Stevenson, 1994). All samples showed a band at: $3,300 \mathrm{~cm}^{-1}(\mathrm{OH}$ stretching of hydroxyls with hydrogen bonds), 3,050 $\mathrm{cm}^{-1}$ (C-H stretching of aromatic ring), 2,950 and 2,850 $\mathrm{cm}^{-1}$ (symmetric and asymmetric vibrations of aliphatic $\mathrm{C}-\mathrm{H}$, probably methyl groups, weaker for FA than for HA and HU spectra), $1,700 \mathrm{~cm}^{-1}$ for HA and HU spectra but absent for FA (this band is usually attributed to $\mathrm{C}=\mathrm{O}$ stretching of $\mathrm{COOH}$ and ketones), 1,660 $\mathrm{cm}^{-1}$ region (asymmetric vibration of $\mathrm{COO}^{-}$ and aromatic, olefin or amide $\mathrm{C}=\mathrm{O}$ ). The band at 1,665 $\mathrm{cm}^{-1}$ could also be attributed to carboxylic acids capable of forming internal hydrogen bonds. Ortho-hydroxybenzoic acids can 
chelate in a similar way to the ortho-hydroxyacetophenones and ortho-hydroxybenzaldehydes, with a correspondingly large shift of the carbonyl frequency. Salicylic acid, an usual HS model, absorbs at $1,655 \mathrm{~cm}^{-1}$, and this is comparable with the shifts experienced with the $\beta$-hydroxy- $\alpha \beta$-unsatured ketones. The $1,597 \mathrm{~cm}^{-1}$ band, which is more intense in the HA spectra, is highly characteristic of the aromatic ring and is attributed to C-C stretching vibrations. The $1,514 \mathrm{~cm}^{-1}$ band could also be attributed to this kind of vibration of ortho- and para- di-substituted and unsymmetrical tri-substituted rings. The region between 1,450 and 1,400 $\mathrm{cm}^{-1}$ corresponds to skeletal $\mathrm{CH}_{3}$ and $\mathrm{CH}_{2}$ deformations of alkanes and these bands are better outlined in the HA and $\mathrm{HU}$ spectra. Bands between 1,260 and $1,220 \mathrm{~cm}^{-1}$ could be due to the C-O stretching in acids, alcohols, ethers and esters. Nevertheless, this is a spectrum region where many strong bands commonly occur and bands in this region can hardly be unequivocally assigned. The bands between 1,100 and $1,000 \mathrm{~cm}^{-1}$ are assigned both to $\mathrm{C}-\mathrm{O}$ stretching and C-N stretching of aliphatic amines. The bands around $950 \mathrm{~cm}^{-1}$ can be associated to polysaccharides and only the FA and HA spectra showed these bands. The region $1,000-650 \mathrm{~cm}^{-1}$ is also associated to out-of-plane deformations of hydrogen atoms remaining on aromatic rings. The bands between 1100 and $1000 \mathrm{~cm}^{-1}$ are usually assigned to inorganic components as clays and quartz. The region between 720 and $630 \mathrm{~cm}^{-1}$ show also organo-sulphur vibrations (Bellamy, 1975). These bands are present in low intensity in the FA and HU but not in the HA spectra.

\section{EPR spectroscopy}

All EPR spectra showed a free radical line at $g=2.00$ region, with average value of $g=2.0037$ for HA, $g=2.0044$ for FA and $g=2.0034$ for HU (Table 4). This line is characteristic of semiquinone radicals, typical of HS. The $g$ values fractions were averagely higher for FA and lower for $\mathrm{HU}$ than for the HA fraction. A higher $g$ value is expected for species rich in oxygenated groups, as the FA case. Moreover, usually FA shows width lines broader than for HA isolated from the same source (Senesi, 1990), which is confirmed by our results. During composting time there is variation in the content of organic free radical of the samples. HU fraction shows a strong variation from the beginning to the end of composting.

The EPR spectra in magnetic field of 5,000 G, room temperature and $77 \mathrm{~K}$, of FA and HA samples present signal of high-spin $\mathrm{Fe}^{3+}$ ions complexed in distorted octahedral structures and/or tetrahedral, in rhombic symmetry coordination, as showed by the asymmetric line in $g=4.3$ (Guimarães et al., 2001). In the HU fraction, however, this signal is very weak indicating a lower iron concentration in this fraction. The spectra at $77 \mathrm{k}$ show signals around $g=$ 9.0 and 6.0, the former being usually attributed to $\mathrm{Fe}^{3+}$ ions in sites with near-orthorhombic symmetry and the latter to high-spin $\mathrm{Fe}^{3+}$ ions in strong axially symmetric crystal fields. This suggests that the iron was bound to four nitrogen atoms in a planar configuration, probably in iron porphyrin structures (Guimarães et al., 2001). The $77 \mathrm{~K}$ spectra also exhibited a complex absorption pattern around $g=2$ region, that shows a hyperfine interaction quadruplet at $\mathrm{g} / /=2.25$ and $\mathrm{A}=175 \mathrm{G}$. This corresponds to copper complexes in inner-sphere, with ligands arranged in a square planar (distorted octahedral) coordination around the central $\mathrm{Cu}^{2+}$ ion. A six lines pattern suggests the presence of manganese complex. The EPR parameters (A = $88 \mathrm{G}$ e $g=2,005)$ are consistent with inerspheres complexes of $\mathrm{Mn}^{2+}$ ions, which are bounded to six oxygen atoms of negatively charged carboxylate and phenolate groups in a distorted octahedral environment (Senesi, 1990).

Table 4. EPR parameters of humic fractions during composting time.

\begin{tabular}{ccccccccccc}
\hline $\begin{array}{c}\text { Sample } \\
\text { /days }^{1}\end{array}$ & \multicolumn{3}{c}{ HA } & \multicolumn{3}{c}{ FA } & \multicolumn{3}{c}{ HU } \\
\cline { 2 - 10 } & g-factor & Lw $*$ & OFR ** & g-factor & Lw * & OFR ** & g-factor & Lw * & OFR ** \\
\hline 0 & 2.0037 & 5.6 & 1.91 & 2.0044 & 7.1 & 1.63 & 2.0033 & 4.1 & 21.2 \\
2 & 2.0037 & 5.2 & 2.54 & 2.0044 & 6.9 & 1.59 & 2.0034 & 4.2 & 16.8 \\
8 & 2.0037 & 5.2 & 2.11 & 2.0044 & 7.0 & 2.46 & 2.0035 & 4.3 & 10.5 \\
15 & 2.0038 & 5.2 & 2.14 & 2.0045 & 6.9 & 2.44 & 2.0034 & 4.3 & 18.0 \\
22 & 2.0037 & 5.3 & 3.00 & 2.0044 & 6.9 & 1.88 & 2.0033 & 4.2 & 19.4 \\
29 & 2.0038 & 5.6 & 2.01 & 2.0045 & 6.7 & 1.85 & 2.0034 & 4.3 & 10.7 \\
Sludge & 2.0039 & 6.3 & 2.72 & 2.0046 & 8.0 & 4.41 & 2.0038 & 5.0 & 6.15 \\
\hline
\end{tabular}

${ }^{1}$ composting days, $*$ Lw $=$ line width in Gauss, ** OFR = organic free radical $\left(\right.$ spin $\left.g-1 \times 10^{16}\right)$ 


\section{Conclusions}

Infrared spectroscopy reveals that compost of sawdust plus paper mill is rather rich in hydroxyls, aromatic and carboxylate, alkyl and carbohydrates groups. The alkyl fraction is concentrated in the HA and HU samples. This technique also showed bands of aromatic $-\mathrm{C}-\mathrm{H}$ confirming the lignin nature of the material.

The decreasing of the $\mathrm{E}_{4} / \mathrm{E}_{6}$ ratio during composting indicates an inherence of the organic chains number, with conjugated double bounds, which can lead to a molecular weight increasing. A decreasing of the $\mathrm{E}_{2} / \mathrm{E}_{4}$ was also observed during the oxygenation period, which corresponds to a reduction of the lignin content and/or formation of porphyrins structures.

The EPR results shows that HU fraction presents the highest concentration of organic free radical and the lowest intensities of the $\mathrm{Fe}^{3+}$ during the composting process. The stronger variation of this signal during the composting process were verified in the HA fraction.

\section{Acknowledgements}

The authors thank the support of CAPES, CNPq, Paraná 12 Meses Program, Tibagi Sistemas Ambientais Ltda. and Iguaçu Celulose Ltda.

\section{References}

BELLAMY, L. J. The infrared spectra of complex molecules. 3rd ed. London: Chapman and Hall, 1975.

BUDZIAK, C. R.; MAIA, C. M. B. F.; MANGRICH, A. S. Transformações químicas da matéria orgânica durante a compostagem de resíduos da indústria madereira. Química Nova, São Paulo, SP, v. 27, n. 3, p. 399-403, 2004.

CHEN, Y.; SENESI, N.; SCHNITZER, M. Information provided on humic substances by E4/E6 ratio. Soil Science Society of America Journal, Madison, v. 41, p. 352-358, 1977.

FOKEN, U.; LIEBEZEIT, G. Distinction of marine and terrestrial origin of humic acids in North Sea surface sediments by absorption spectroscopy. Marine Geology, Amsterdam, v. 164, p. 173-181, 2000.

GOYAL, S.; DHULL, S. K.; KAPOOR, K. K. Chemical and biological changes during composting of different organic wastes and assessment of compost maturity. Bioresource Technology, Essex, v. 96, n. 14, p. 1584-1591, 2005.
GUIMARAES, E.; MANGRICH, A. S.; MACHADO, V. G.; TRAGHETTAC, D. G.; LOBOC, M. A. Criterious preparation and characterization of earthworm-composts in view of animal waste recycling. Part II. A synergistic utilization of EPR and H-1 NMR spectroscopies on the characterization of humic acids from vermicomposts. Journal of the Brazilian Chemical Society, São Paulo, SP, v. 12, n. 6, p. 734-741, 2001.

JERZYKIEWICZ, M.; DROZD, J.; JEZIERSKI, A. Organic radicals and paramagnetic metal complexes in municipal solid waste composts. An EPR and chemical study. Chemosphere, Oxford, v. 39, n. 2, p. 253-268, 1999.

MAIA, C. M. B. F.; MANGRICH, A. S.; SIMONELLI, F. Spectroscopic characterization of organic structures and organicinorganic interactions on paper mill sludge. Acta Hydrochimica Et Hydrobiologica, Weinheim, v. 28, p. 372-377, 2001.

MAIA, C. M. B. F. Acompanhamento do processo de compostagem da serragem de Pinus taeda pelas características químicas e espectroscópicas das substâncias húmicas em formação. 2003. 102 f. Tese (Doutorado em Química) - Universidade Federal do Paraná, Curitiba.

NEBBIOSO, A.; PICCOLO, A. Advances in humeomics: enhanced structural identification of humic molecules after size fractionation of a soil humic acid. Analytica Chimic Acta, v. 720, p. 77-90, 2012.

PICCOLO, A.; CONTE, P.; TAGLIATESTA, P. Increased conformational rigidity of humic substances by oxidative biomimetic catalysis. Biomacromolecules, Washington, US, v. 6, p. 351-358, 2005.

PICCOLO A. The supramolecular structure of humic substances. Soil Science, Baltimore, v. 166, p. 810-833, 2001.

PICCOLO, A.; CELANO, G.; CONTE, P. Methods of isolation and characterization of humic substances to study their interactions with pesticides. In: CORNEJO, J.; JAMET, P. (Coord.). Pesticides/soil interactions: some current research methods. Paris: INRA, 2000. p. 103-116.

SANTOS, G. A.; CAMARGO, F. A. O. Fundamentos da matéria orgânica do solo: ecossistemas tropicais e subtropicais. Porto Alegre: Gênesis, 1999.

SENESI, N. Application of electron spin resonance (ESR) spectroscopy in soil chemistry. Advances in Soil Science, New York, v. 14, p. 77-130, 1990.

STEVENSON, F. J. Humus chemistry: genesis, composition, reactions. 2nd ed. New York: Wiley, 1994.

VEEKEN, A.; NIEROP, K.; WILDE, V. de; HAMELERS, B. Characterization of $\mathrm{NaOH}$-extracted humic acids during composting of a biowaste. Bioresource Technology, v. 72, p. 33-41, 2000. 